\title{
THE TRANSACTION FOOTPRINTS OF SCOTTISH FOOD AND DRINK SMES
}

\author{
Andrew Copus ${ }^{1}$, Jonathan Hopkins ${ }^{2}$ and Rachel Creaney ${ }^{3}$
}

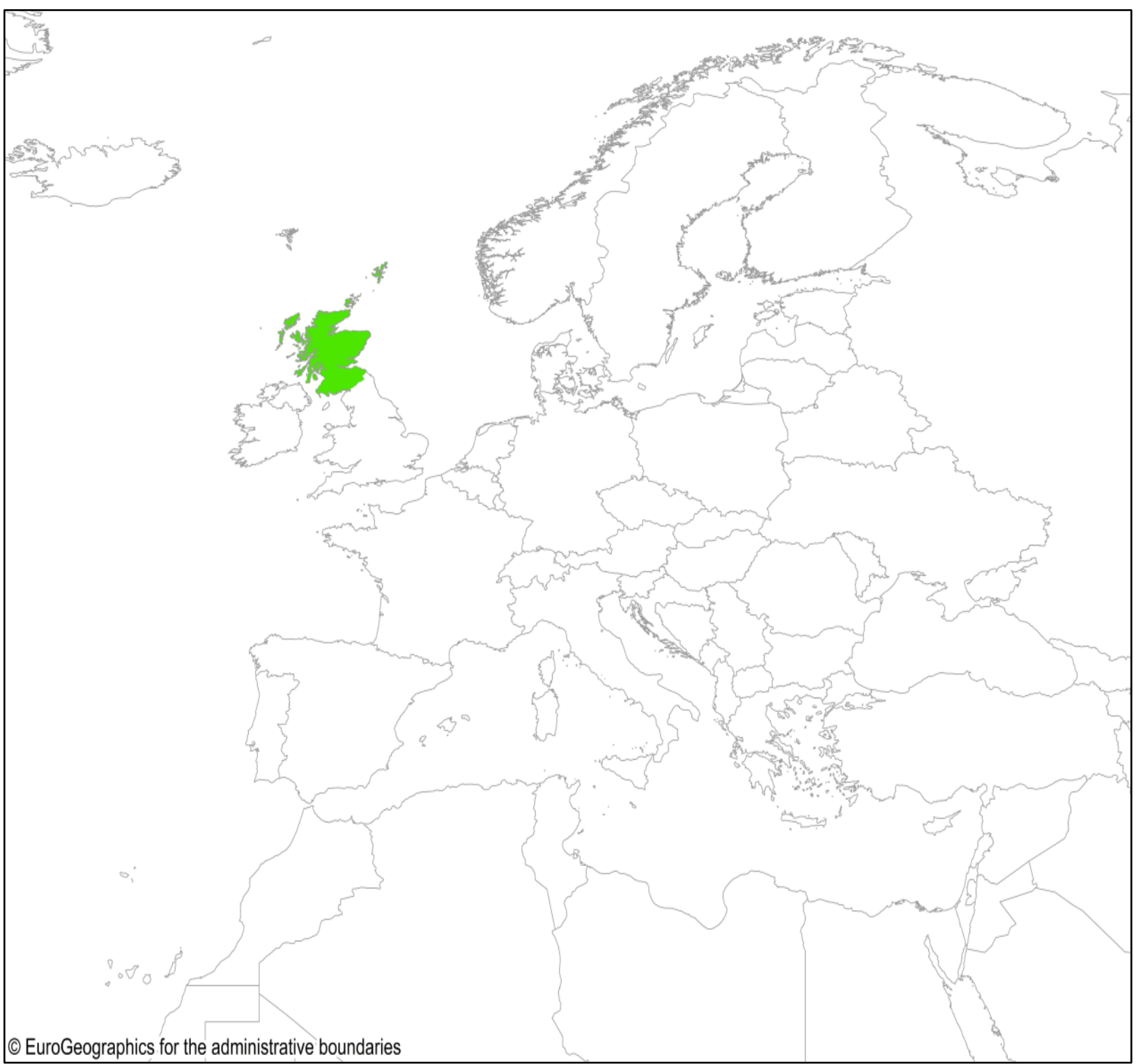

1 Corresponding author, Social Economic and Geographical Sciences Group, The James Hutton Institute, Craigiebuckler, Aberdeen, AB15 8QH, Scotland, UK; e-mail: andrew.copus@hutton.ac.uk

2 jonathan.hopkins@hutton.ac.uk

3 rachel.creaney@hutton.ac.uk 
Abstract: This paper presents a survey approach to measuring the "transaction footprints" of rural small and medium sized enterprises (SMEs). Combined with a graphical presentation of results, this contributes to the evidence base on the roles of local and global linkages. Findings suggest that the food and drink industry of Scotland is relatively localised in its input and sales interaction pattern, although substantial variations, associated with product specialisms, remoteness/ accessibility, input purchasing and marketing strategies, exist. Localised SMEs have weathered the recession slightly better, but more outward-looking in firms tend to have greater optimism about the future. Transaction footprint analysis should be viewed as component of an ongoing process of re-mapping the network infrastructure of the rural economy, alongside analysis of untraded interdependencies, and institutional networks in the realm of governance.

Keywords: Transaction footprints, food and drink, re-localisation, networked rural development.

\section{Introduction}

This paper presents a simple survey-based method of measuring the spatial "transaction footprints" of rural small and medium sized businesses (SMEs). Although the approach could be used to study SMEs from any sector, we focus on the food and drink industry in Scotland. This choice reflects the fact that, in addition to a cross sectoral interest in the relative importance and roles of local and wider interaction as determinants of rural development and resilience, we hope our findings provide helpful empirical evidence in relation to recent theorizing regarding the role of re-localisation of the food industry as a means of regenerating rural economies.

\section{The long and the short of it...}

Although the specific focus of this paper is upon the spatial transaction patterns associated with food and drink companies in Scotland, the key issue addressed has a wider resonance across rural and regional development theory. Various "strands" of literature highlight the importance of both "placial embeddeness" (Korsgard et al. 2015) in dense local networks, and effective engagement with wider markets and the diffuse sources of information, finance, and other forms of support necessary for the innovation which leads to adaptation and growth.

In the rural development literature this balance is emphasised by the proponents of "neoendogenous" development (Ray 2006). For example, according to Bosworth (2010 p. 39) "...valorising local attributes while appreciating the importance of extralocal connectivity... is central to theories of neo-endogenous development." Similar ideas have been presented through the lens of "networked development" (Murdoch 2000, Murdoch 2006, Shucksmith 2013). Various elements of the regional development literature, such as the work on industrial districts (Piore and Sable 1984, Murdoch 2000), or the concept of place-based policy (Barca 2009) also highlight the need for both local interaction and global links.

Although the announcement of the "death of distance" (Cairncross 1997) is now widely recognised to have been exaggerated, or at least premature, in the succeeding decades various concepts have been propounded which challenge the significance of local interaction, on the grounds that transport, travel and communications technology are reducing the "friction of distance", and privileging various forms of "organised proximity" (Boschma 2005, Torre and Rallet 2005). Clearly such ideas bring into question not only the role accorded to agglomeration economies in much regional policy, but also suggest a need to reconsider the assumptions of place-based and neoendogenous development paradigms.

All these ideas have been articulated at a rather general level, but if we focus on the topic of business networks, and those of rural SMEs in particular, a number of writers have also emphasised the need for an appropriate balance between (to use Harold Bathelt's colourful expression) "local buzz and global pipes" (Bathelt et al. 2004, Bathelt and Glückler 2010). There is some evidence (Dubois et al. 2012, Young 2010a, 2010b) to suggest that in remote regions, 
where local markets are small, and specialising in high quality niche market products, - for which prices can cover higher delivery cost, - is a sound survival strategy, the balance shifts towards the global. On the other hand Bosworth $(2008,2012)$ has argued that "commercial counterurbanisation" has introduced many urbanite entrepreneurs into accessible rural areas of the North of England, bringing with them a wider set of contacts than that of "indigenous" business leaders. Korsgaard et al. (2015 p. 594), in a qualitative study of entrepreneurs situated on islands in Denmark, stress the importance of entrepreneurs both "leveraging their placial embeddedness and non-local strategic networks to create opportunities." However, in contrast to Bosworth, they report: "We also found to a very large extent that the non-local networks leveraged were built after the entrepreneurs had moved to their new rural island settings." (ibid.)

\section{The relocalisation paradigm}

Narrowing the perspective in a different way, onto the food and drink industry and associated activities, brings into view a body of literature and a cluster of approaches which seems to privilege local interaction and treat globalisation as a hostile influence. Whilst there is a substantial literature on short supply chains, local foods, regional products, and so on, we will focus here on the more synthetic concept of "re-localisation", in its various manifestations, in contrast to "delocalisation".

Fonte (2008 p. 203) explains that "Reducing the physical distance between producers and consumers is thought to revitalise rural communities, benefiting local farmers on the one side and consumer and environmental health on the other." Sonnino and Marsden (2006) argue that "Sustainable Rural Development" (relocalisation) has taken off in some parts of Europe (including Italian regions) more successfully than others, and that it is essentially competing against what Crowley et al. (2008) term "para productivist" agriculture, (de-localisation). The key difference between the two forms of development is the extent to which economic benefits are retained in the countryside, rather than transferred into globalised markets.

According to Marsden (2009 p. 121) "In contrast to the dominant agri-industrial model that tends to assume atomistic farms and neoclassical farmers, the [relocalisation] rural development model suggests a recreated potential for symbiotic interconnectedness between networks of farms and farmers in the same locale and regions.". In a later paper (Marsden 2010 p. 225) he argues that evolving localised food and drink or "eco-economy" networks can become the driver of "regionalized rural development" processes, "driven by complex sets of internally and externally generated interrelationships and interactions, which shape the relative attractiveness of rural spaces economically, socially, culturally and environmentally". What is interesting about Marsden's perspective is that although he believes (2009 p. 121) that re-localisation requires "a radical rupture with ...agri industrial processes", he also clearly states "that it is possible to rebuild differentiated rural development in ways that increase interactions with the external economy at the same time as maximising the ways in which more economic and social value can be fixed in rural spaces...." (italics added).

\section{As long as a piece of string...?}

A substantial proportion of the evidence relating to the interaction patterns of small businesses, and their role in rural/regional development, together with the literature on food and drink relocalisation, is qualitative or anecdotal. This is not surprising, given the intangible nature of some forms of linkage, such as those associated with exogenous sources of technical information or market intelligence, or the trusting and supportive relationships which are part of "placial embeddedness" (Korsgaard et al. 2015). It can be argued, of course, that statistical significance may be sacrificed in the interest of deeper understanding of the processes affecting specific examples within their own milieu. However there are also risks, especially if the object of study (such as food and drink localisation) is closely linked to ideological debates, and any progress which can be made in terms of objective quantification is surely to be welcomed.

There have been some interesting attempts to measure and quantify interaction patterns, and we will briefly review a selection of these before describing the exercise which forms the basis of this paper. A useful preliminary step is to make the distinction between the two principal types of 
interaction: market transactions (involving goods or services) and non-market interactions (usually exchanging information). Treating these separately is appropriate because not only are market transactions more amenable to localisation, especially if goods, or services requiring faceto-face contact, are involved, but also because they are much easier to measure. It is important, of course not to confuse ease of quantification with significance. Indeed the importance of "untraded interdependencies" (Storper 1995) has long been recognised in the regional development literature.

It is perhaps also worth pointing out that quantification is usually associated with "space" rather than "place", since the former is objective, and can be defined in ways which have common meanings to survey respondents, whilst the latter incorporates subjective associations which tend to vary between respondents. Thus according to Korsgaard (2015 p. 579) "Space is... related to the movement and flow of capital, labour, resources and information, and dominated by economic concerns relating to the optimization of profit or accumulation of economic value for companies, countries and regions...Place, on the other hand, denotes an evaluation of a location in relation to lived life and experience.... A location becomes a place if meanings and experiences are attached to it." This seems to be equivalent to what Watts et al. (2011 p. 1188) term "empirical space", as opposed to "place space", or "image space".

Attempts to quantify interaction patterns have generally involved surveys of business owners or managers (Copus et al. 2003, Kalantarides and Bika 2006, Bosworth 2008, Copus et al. 2011, Dubois et al. 2012). Similar methods have been employed in the study of the economic footprints of small towns (Mitchell and Courtney 2006, Courtney et al. 2007, Courtney et al. 2008), and the transaction patterns of farms (Pangbourne and Roberts 2014). Usually such questionnaires include a range of questions about the characteristics of the business, size, products, attributes of the entrepreneur, recent performance and so on. However, most important in terms of the capacity to measure interaction patterns are questions about sources of inputs, outputs (which capture transaction patterns) and questions about sources of advice, funding, membership of representative organisations, industry bodies, and local fora of various kinds (to capture nontransaction linkages). Usually the questions involve locating sources/destinations of transactions or non-market interactions across a range of concentric zones. The inner zones are generally measured in physical distance, or travel time, whilst the outer zones are associated with administrative entities, such as regions, countries, Europe, or the rest of the world. The number of zones varies, from four (Copus et al. 2011) to eight (Courtney et al. 2007, 2008). Telephone or postal surveys are commonly followed up with a smaller sample of face to face interviews, in order to collect qualitative data both to aid interpretation, and to better understand patterns of nonmarket interaction which are less well captured by the quantitative questions.

The AsPIRE project (Copus et al. 2003) carried out a survey of business transaction patterns in six European countries. It was found that firms in Scottish, Irish, German and Finnish case study areas had more extensive interaction patterns, compared with those in case studies in Spain and Greece. Food manufacturing firms tended to have more compact transaction patterns than those in other manufacturing activities or services. There was evidence of an association between higher levels of education of the entrepreneur or manager and a more extensive transaction pattern, at least on the input side. Finally those who claimed to be more innovative tended to carry out more transactions outside their region and outside their country.

Another European project, DERREG, further developed the survey methodology, using an electronic questionnaire, followed by in-depth, face to face interviews, centred on an "actor network map", in case study areas in Sweden, Netherlands, Czech Republic, Slovenia and Lithuania (Copus et al. 2011). Findings were explored through the lens of the concept of "translocal globalisation" (Dubois et al. 2012), arguing that even the remotest rural environments where many aspects of small business networking are tied into local contexts, can nevertheless develop, and benefit from, strong exogenous links.

The following two examples from the UK are focused on the relationship between (demographic) counter-urbanization and entrepreneurial activity. In Kalantarides and Bika's (2006) survey of rural businesses in Cumbria many questions are directed to revealing differences in degree of local embeddedness between in-migrant and locally born entrepreneurs. This leads to a broader 
interest in perceptions of, and attitudes to, the local business environment. They conclude (op cit. p.125) that the evidence "suggests that the embeddedness of entrepreneurship differs significantly between in-migrant and locally-born entrepreneurs. The former appear to exploit less local sources of capital, material, output markets as well as information regarding markets, and localized knowledge while the reverse is the case regarding the latter...".

Similarly, Bosworth (2008 p. 365), using a survey in rural North East England, found that "inmigrants conduct significantly less trade at the local level (defined as a 30-mile radius) than their local counterparts" and that "more of the income generated by in-migrants originates from outside the local economy. They make $50 \%$ more sales regionally, and $100 \%$ more sales nationally and internationally compared to locally owned firms."

Having explained the importance of transaction patterns in terms of rural and regional development theory, and briefly described previous empirical analysis relating to this issue, we will now turn to the specific context of the survey which forms the body of this paper; food and drink processing in Scotland.

It is perhaps important to reiterate at this point that we have selected food and drink processing as an example of an activity which is in many ways rooted in rural areas by its supply chain, primarily in order to shed light on the "local buzz" vs. "global pipes" debate. We see the recent interest in "local food" and short supply chains as bringing into sharp focus an issue which is broadly relevant across most sectors of the changing rural economy. Since the re-localisation of the food and drink industry is a world of research of its own, there will undoubtedly be many questions specific to this research theme which we will neglect due to our focus upon the spatial interaction patterns of rural enterprises.

Having provided a brief account of the literature relating to transaction patterns, explaining their significance to small business development in the rural economy, we will now turn to the context of our empirical research, - the Scottish food and drink industry,- before presenting our survey methodology and findings.

\section{The Scottish Food and Drink Industry}

According to the Scottish Government's Annual Business Statistics (Scottish Government 2013a) the food, beverages and tobacco sector (Standard Industrial Classification Divisions 10-12) has been the largest single manufacturing industry group in terms of contribution to national Gross Value Added (GVA) in every year since calculations began in the current format (i.e. from 20082013). This group of activities accounts for $31 \%$ of Scottish manufacturing GVA, $24 \%$ of manufacturing employment, and $12 \%$ of manufacturing firms ${ }^{4}$. The food and drink processing industry of Scotland has grown strongly in recent years, achieving a turnover target set by the Scottish Government ( $£ 12.5 b n)$ six years early in 2013 (Scottish Government 2013b). A new target of $£ 16.5 \mathrm{bn}$ has been set for 2017 .

The term "food and drink industry" is often used in a broad sense, to include primary producers (agriculture and fisheries), and also businesses which are essentially wholesalers, retailers or distributors. Our analysis below relates primarily to the processing part of the industry (though some processors may have some involvement in either primary production or distribution too). According to the Interdepartmental Business Register (IDBR, Scottish Government 2015), in March 2015 there were 740 food processing businesses in Scotland and a further 165 manufacturers of beverages. Together these accounted for $0.5 \%$ of the private enterprises recorded in the IDBR. However they accounted for $2.4 \%$ of total employment and $4.2 \%$ of turnover recorded by IDBR companies. All but 55 of the 905 food and drink companies had less than 250 employees, and are therefore defined as small or medium sized enterprises (SMEs).

Several recent analyses relating to the Scottish food and drink industry, (llberry and Maye 2005a, 2005b, 2006 and Watts et al. 2011) focus on the "local food" segment. As a consequence of this

\footnotetext{
${ }^{4}$ The definition of the industry used here excludes primary producers (agriculture and fisheries) and includes tobacco processing.
} 
perspective, the authors find it necessary to cast the net wider than the present study, by including retailers as well as processors.

Watts et al. (2011) make a very comprehensive review of the distribution and characteristics of "local" food producers/retailers in Scotland, based on information gleaned from 32 business directories. The 723 "local food enterprises" included in the resulting database are essentially self-defined and include "producers, processors, and retailers of both local and regional foods..." (ibid. p. 1190). Just over half of these are primary producers. Local food enterprises (whether farm based or not) tend to be located outside the major built up areas. In comparison with English regions, the incidence of food and drink localisation activity in Scotland is at a lower level than in South West and South East (the leading regions), but higher than the least localised English regions (North East, East Midlands, London) and Wales. Interestingly Watts et al. suggest that the relatively denser distribution of local food enterprises in the north and west of the country may be evidence of the survival of local food systems associated with crofting.

Ilberry and Maye (2006) report on a set of case studies carried out in the Scottish Borders and Northumberland. Unusually, these are designed to reconstruct supply chains "backwards" or "upstream" from food retailers which claim to be specialising in local food. Presenting supply chains in graphics, these case studies reveal the variety to be observed in the "local food" sector. However the retailer perspective makes it difficult to tease out implications in terms of the transaction patterns of processors, which is the focus of the current paper. What is clear however, from this and two related papers (llberry and Maye 2005a, 2005b) which focus on livestock supply chains and sustainability aspects respectively, is that the notion of a distinct, separate, "local food" industry is not evidenced empirically in the Borders/Northumberland context. "Binary opposites such as 'local/global' and 'conventional/alternative' are therefore difficult to maintain because both global (conventional) and local (alternative) are linked together in an overall agro-food system. It may be more instructive therefore to think instead about hybrid food spaces, implying a 'mixing together', rather than separate systems." (Ilberry and Maye 2006 p. 354).

\section{The Transaction Footprint Survey and Database}

The survey on which this paper is based was carried out in September-October 2015. The objective was to collect semi-quantitative data on the transaction patterns of the Scottish food and drink industry. In terms of the concepts and literature cited above, the intention was to explore the extent to which this industry's transaction patterns are localised or globalised, and whether their orientation in this respect was associated with particular products, sectors, or enterprise characteristics, and with strong or weak performance.

The survey took the form of a postal questionnaire accompanied by the option of completing an on-line version if the respondent preferred. The majority of the questions were "closed", with qualitative responses minimised. The address list of food and drink businesses to which the questionnaire was sent was extracted from the Companies House register (November 2014 version ${ }^{5}$ ). All businesses registered under Standard Industrial Classification (SIC) Groups 10.110.8, (i.e all food and drink processing companies, but excluding primary processors and retailers) with postal addresses of registered offices within Scotland, were included. The list thus excludes larger companies registered outside Scotland, but with branch plants within Scotland. However, since the focus is upon SMEs these would have, in any case, been excluded, together with Scottish companies employing 250 or more. Obviously "dormant" companies were excluded. A total of 910 companies were thus identified, a reassuringly similar number to that recorded in the IDBR (905). A pilot survey was sent to 48 (urban) addresses, which were later excluded from the full survey. Responses were received from 102 companies. Of these 5 were excluded because, having 250 or more employees, they do not qualify as SMEs. This implies a net response rate of approximately $11 \%$ (i.e. 97 full responses out of 862 companies contacted). Data analysis was carried out using $\mathrm{R}$ ( $\mathrm{R}$ Core Team, 2015a) including use of the 'foreign' package (R Core Team, 2015b), spatial analysis used ArcGIS (ESRI, 2013).

\footnotetext{
${ }^{5}$ Companies House is the official body in the UK responsible for the register of limited companies. A public summary of the register is available at http://download.companieshouse.gov.uk/en_output.html [accessed 29th March 2016].
} 


\section{The Urban-Rural distribution of the Companies House population, and the respondents}

The location of the postcodes of the registered offices of the all the food and drink companies recorded in the Companies House register is shown in Figure 1. The classification of these locations according to the Scottish Government's 2013-14 six-fold rural-urban classification (Scottish Government 2014) is shown in Table 1, (and Figure 1), together with the production site locations (which may be different) of the $97^{6} \mathrm{SME}$ respondents to the survey.

Tab 1. Registered Companies and Respondents Production Sites by Scottish Government Rural-Urban Classification

\begin{tabular}{|l|r|r|r|r|}
\hline Rural-Urban Category & $\begin{array}{r}\text { Register Offices } \\
\text { (Companies House Register) }\end{array}$ & \multicolumn{2}{r|}{$\begin{array}{r}\text { Production Sites } \\
\text { (Survey Respondents) }\end{array}$} \\
\hline & Number & $\%$ & Number & $\%$ \\
\hline Large Urban Areas & 333 & 36.6 & 21 & 21.6 \\
\hline Other Urban Areas & 229 & 25.2 & 23 & 23.7 \\
\hline Accessible Small Towns & 60 & 6.6 & 8 & 8.2 \\
\hline Remote Small Towns & 47 & 5.2 & 9 & 9.3 \\
\hline Accessible Rural & 126 & 13.8 & 10 & 10.3 \\
\hline Remote Rural & 115 & 12.6 & 25 & 25.8 \\
\hline Unidentified & 0 & 0 & 1 & 1.0 \\
\hline
\end{tabular}

The response rate varied between the rural-urban categories, urban areas being less well represented, whilst the small towns and remote rural areas were relatively well represented. The lower response rate in the urban areas is due in part to the exclusion of the firms which had already been contacted for the pilot survey. In the case of small towns and rural areas, all registered food and drink companies were sent a questionnaire, and the variation in response rates is difficult to explain. The absolute number of respondents from the small town categories is too small to produce meaningful results, and in the following analysis these categories will be combined with the corresponding rural categories (accessible or remote).

\section{Overview of the Questionnaire}

The questionnaire (Appendix 1) begins by establishing the location of the production site, the number of employees, whether the owner/manager considers the firm to be orientated to the mass market or a niche market, and the type of food or drink produced. This is followed by a series of simple "tick box" questions about the sources of inputs, direct from producer or "catcher", from a series of concentric zones (from "within an hour's travel time" to "outside the UK"), and from rural or urban sources. Similar questions about customers follow, but in addition differentiating between sales to consumers and businesses of different sizes. Distribution methods are covered by a question about the use of the internet for both purchasing and sales, and by another question about different logistic solutions. The survey ends with a pair of attitudinal scaling questions about whether the business is currently, and in future, following a strategy of localisation or globalisation. The analysis which follows does not draw on the entire database, but centres on the information acquired regarding the origins of inputs and destinations of sales, cross-tabulated against various characteristics of the SMEs.

\footnotetext{
${ }^{6}$ The location of one company's production site was not established. This company is excluded from the results in the tables and graphs below.
} 


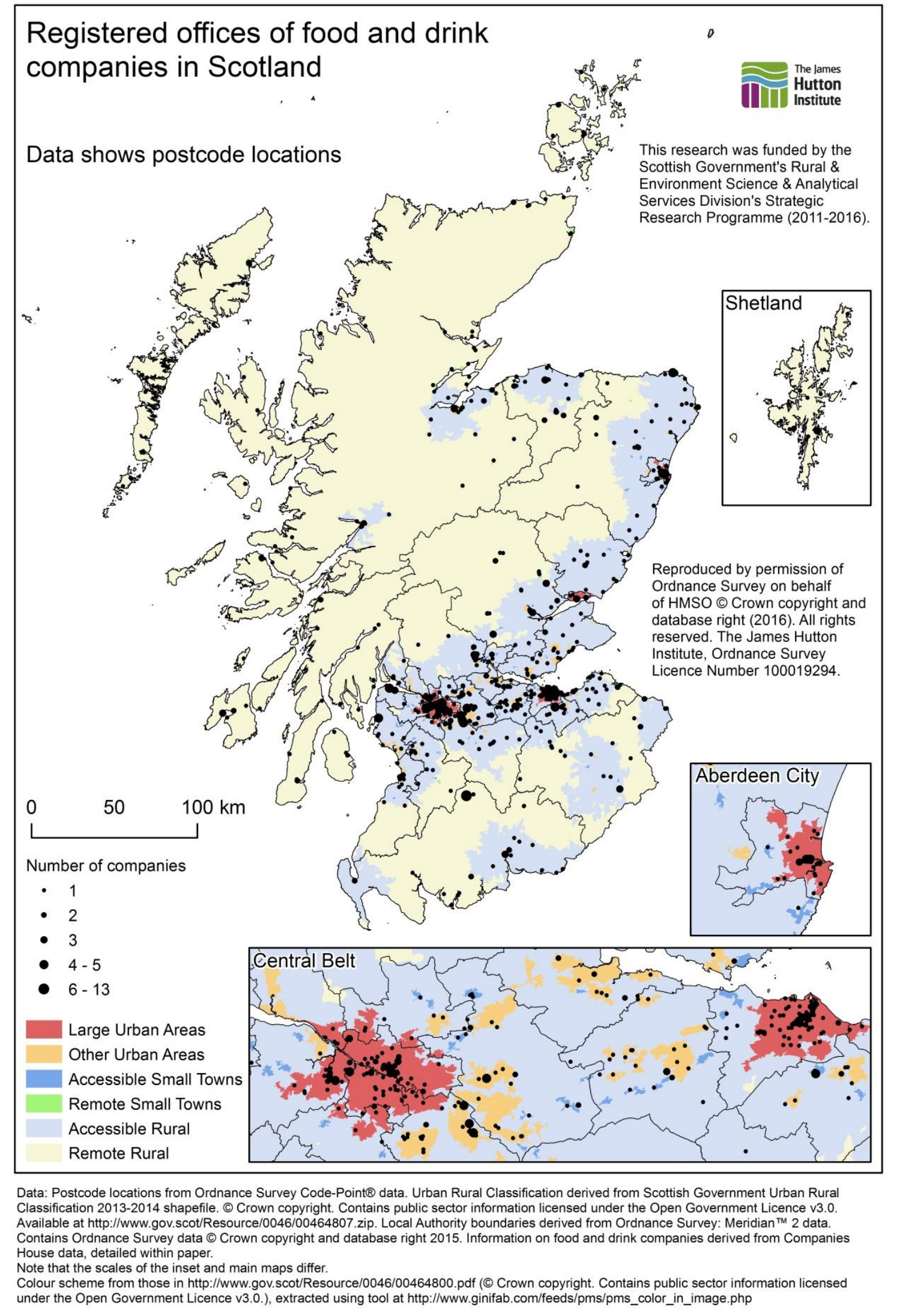

Fig 1. Dot map showing location of Registered Offices of Food and Drink Companies in Scotland.

\section{Transaction Footprint Visualisation}

Although attempts have been made to measure transaction patterns for many years, using a variety of survey-based methodologies, a simple and clear means of visualisation of findings has yet to emerge. The following procedure is based upon the questions incorporated in 
the survey of Scottish food and drink producers, combined with a graphical format similar to population pyramids, and implemented within Excel. The grey bars on the left show the mean percentage share of inputs transactions from suppliers in four distance zones. The black bars on the right show the mean percentage share of sales to the same four zones. In both cases the questionnaire asked the respondents to estimate the percentage share of transactions (rather than value or volume) accounted for by each zone. Experience with a previous survey (Copus et al. 2011, Dubois et al. 2012) has shown that estimating shares of value or volume of inputs and outputs is more difficult for the respondents, and the additional complexity acts as a disincentive to completing the questionnaire. It is important to keep in mind that the bars represent a mean of the respondents' estimate of the percentage of input or sales transactions associated with each concentric zone. Because each of the bars is an average of the percentage shares estimated by individual respondents they do not necessarily sum to 100 .

The figures shown to the left and right of the bars in Figure 2 are the input and sales localisation ratios. These are simply the ratio of the mean percentage of transactions in the within 1 hour category (the bottom bar) to the total of the mean percentages of the three other categories, in the bars above. The larger the ratio the more localised the transaction footprint, and vice versa.
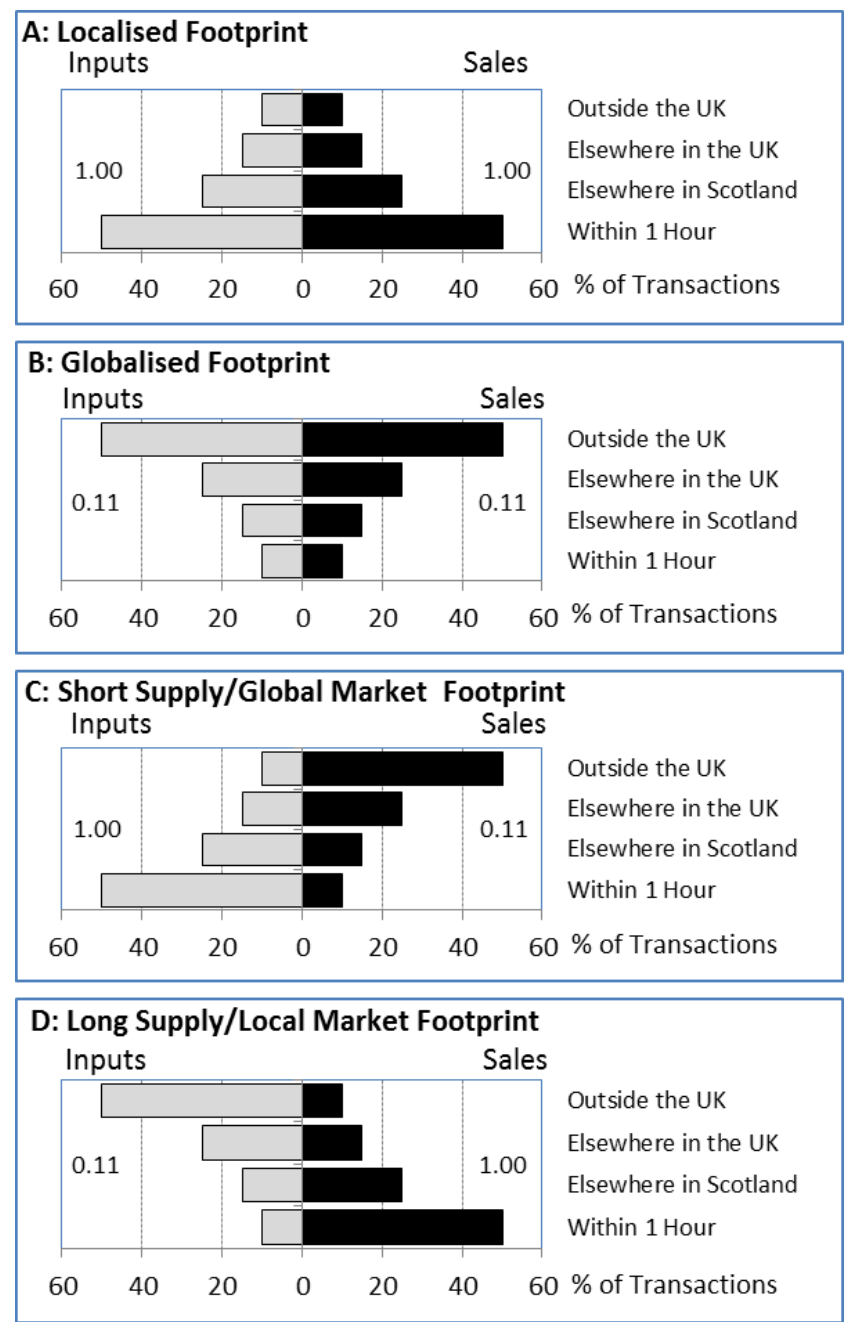

Fig 2. Four Idealised Transaction Footprints.

Figure 2 illustrates the procedure by presenting four "idealised" kinds of transaction footprints. Diagrams $A$ and $B$ show two symmetrical footprints, where input and customer interaction patterns are mirror images of each other, being either localised or globalised. Diagrams C and D illustrate asymmetric footprints, combining $(\mathrm{C})$ a short supply chain with a global marketing strategy, and (D) a globalised pattern of input purchasing with a relatively localised pattern of sales. Type C could, for example, be associated with a regional appellation product which is of such quality (and high price) that it is distributed all over Europe. At the other extreme Type D could be a processed 
food (such as a bakery product) which incorporates ingredients from across the country or further afield, but is relatively low priced and therefore has a predominantly local market. These four types of footprint are helpful in trying to interpret the results of the survey, acting as patterns against which to compare those of various subgroups within the respondent sample.

\section{Summary of Findings}

\section{Products, Supply Chain, and Marketing Strategies of Respondents in Urban, Accessible and Remote Areas}

Before beginning to explore what the data can tell us about transaction footprints it will be helpful to describe the sample of respondent businesses in terms of their product(s), their place in the supply chain, and their market orientation. In keeping with the subsequent footprint analysis the three geographical groups (based on a simplified version of the Scottish Government RuralUrban typology) will be distinguished: urban, accessible (rural+small towns) and remote (ditto).

The majority (81) of the businesses were specialised in a single product group. The remaining 15 SMEs were selling in multiple product groups, the majority (14) to just two or three. The largest single product group among the responding firms, accounting for 25 businesses, was bakery products. Other product groups present in larger numbers were alcoholic drinks (18) meat products (15), fish/seafood (13) and dairy/cheese (12). The remaining firms were involved with a range of other food and drink categories (Table 2 ).

Tab 2. Product Groups represented among the respondent firms.

\begin{tabular}{|l|r|r|r|r|}
\hline & Urban & Accessible & Remote & All SMEs \\
\hline Bakery products & 14 & 5 & 6 & 25 \\
\hline Dairy/cheese & 4 & 3 & 5 & 12 \\
\hline Drinks: alcoholic & 7 & 3 & 7 & 18 \\
\hline Drinks: non-alcoholic & 8 & 1 & 0 & 9 \\
\hline Fish/seafood & 6 & 1 & 6 & 13 \\
\hline Fruit/vegetables & 1 & 1 & 2 & 4 \\
\hline Grains/cereals & 2 & 1 & 1 & 4 \\
\hline Meat products & 9 & 3 & 3 & 15 \\
\hline Processed/ready meals & 5 & 2 & 3 & 10 \\
\hline Other & 6 & 3 & 4 & 13 \\
\hline
\end{tabular}

About a third (30) of the respondent firms obtained all of their inputs directly from producers or catchers (Table 3), almost as many (27) obtained more than $50 \%$ of their inputs from such sources, whilst 21 obtained all their inputs from intermediate processors.

Tab 3. Proportion of inputs received direct from primary producer/catcher.

\begin{tabular}{|l|l|l|l|l|}
\hline & $0 \%$ & $1-50 \%$ & $51-99 \%$ & $100 \%$ \\
\hline Rural-Urban Category & \multicolumn{4}{|l|}{ Percentage of Respondents } \\
\hline Urban Areas & 31.8 & 11.4 & 27.3 & 29.5 \\
\hline $\begin{array}{l}\text { Accessible } \\
\text { Rural/Towns }\end{array}$ & 22.2 & 16.7 & 27.8 & 33.3 \\
\hline Remote Rural/Towns & 32.4 & 8.8 & 29.4 & 29.4 \\
\hline All companies & 29.9 & 11.3 & 27.8 & 30.9 \\
\hline
\end{tabular}

Almost exactly half the respondent SMEs considered themselves to be following a niche marketing strategy (Table 4). Only $17(18 \%)$ claimed to be supplying a mass market, whilst $29(31 \%)$ were following a mixed strategy. On average $38 \%$ of all customers were final consumers and $57 \%$ of sales were to other businesses (processors, wholesalers or retailers). 
Tab 4. Marketing Strategy by (simplified) Urban-Rural Classification.

\begin{tabular}{|l|l|l|l|l|r|r|r|}
\hline & $\begin{array}{l}\text { Niche } \\
\text { Market }\end{array}$ & $\begin{array}{l}\text { Mass } \\
\text { Market }\end{array}$ & Both & B2B & B2C & $\begin{array}{l}50 \% \text { to B, } \\
50 \% \text { to C }\end{array}$ \\
\hline Rural-Urban Category & Percent. of Respondents & \multicolumn{4}{|c|}{ Respondents } \\
\hline Urban Areas & 46.3 & 22.0 & 31.7 & 25 & 12 & 4 \\
\hline $\begin{array}{l}\text { Accessible } \\
\text { Rural/Towns }\end{array}$ & 61.1 & 16.7 & 22.2 & 6 & 8 & 2 \\
\hline Remote Rural/Towns & 52.9 & 14.7 & 32.4 & 18 & 9 & 7 \\
\hline All companies & 51.1 & 18.1 & 30.9 & 49 & 30 & 13 \\
\hline
\end{tabular}

Note: $\mathrm{B} 2 \mathrm{~B}=$ Business to Business, $\mathrm{B} 2 \mathrm{C}=$ Business to Consumer (direct marketing). Number of respondents identifies those SMEs for which $50 \%$ or more of their sales are in this category.

\section{Food and Drink SMEs have relatively localised transaction footprints}

Given the perishability/bulkiness of raw materials and some of the products it is perhaps not very surprising to discover that food and drink SMEs have relatively localised footprints (Figure 3). Across the respondent firms as a whole an average of $37 \%$ of all inputs come from within an hour's travel time of the production site, and a further $29 \%$ from elsewhere in Scotland. The input localisation ratio is 0.68 . On average $47 \%$ of all outputs are sent to customers within an hour's travel time, and a further $25 \%$ are sold to customers within Scotland. This sample of Scotland's food and drink SMEs sold (on average) only $11 \%$ of their products to the rest of the UK, and less than $10 \%$ outside the UK. The sales localisation ratio is thus even higher than that for inputs, at 1.05 .

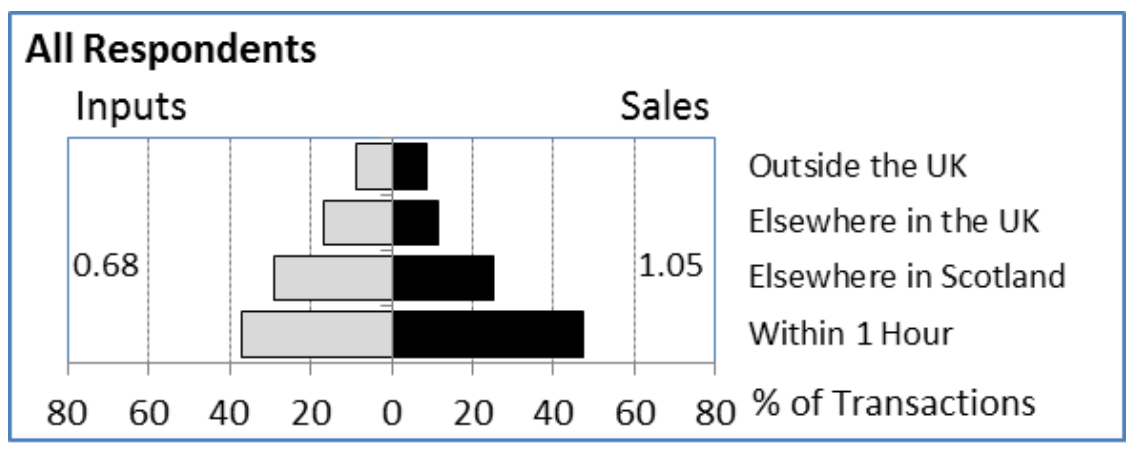

Fig 3. Transaction Footprint, all respondents.

The first impression (based on our sample of SMEs) is therefore not of a globalising, export orientated industry (even though about half of them claim to be orientated towards niche markets), but rather of a group of firms seeking to supply predominantly local demands, and using mostly local inputs. It is however important to keep in mind that the transaction footprint above does take account of the variations in the value of transactions, and that the longer distance transactions may be, on average, of higher value. Also, as a word of caution, we should note that the standard deviations associated with these averages are relatively large, indicating that the size of the footprint varies substantially from firm to firm. It is not clear to what extent this is due to the mixing of localised and non-localised businesses, the "hybridity" of individual firms, or the difficulty of estimating the pattern of transactions, due to this being an unfamiliar thing for respondents to be asked to do.

\section{Remote location generally means a broader footprint...}

Although there is a large degree of variability in all the subgroups within the data, Figure 4 suggests that SMEs in remote areas tend to have greater engagement (both in terms of inputs and outputs) with suppliers and markets outside Scotland than those situated in accessible rural/small town areas. 

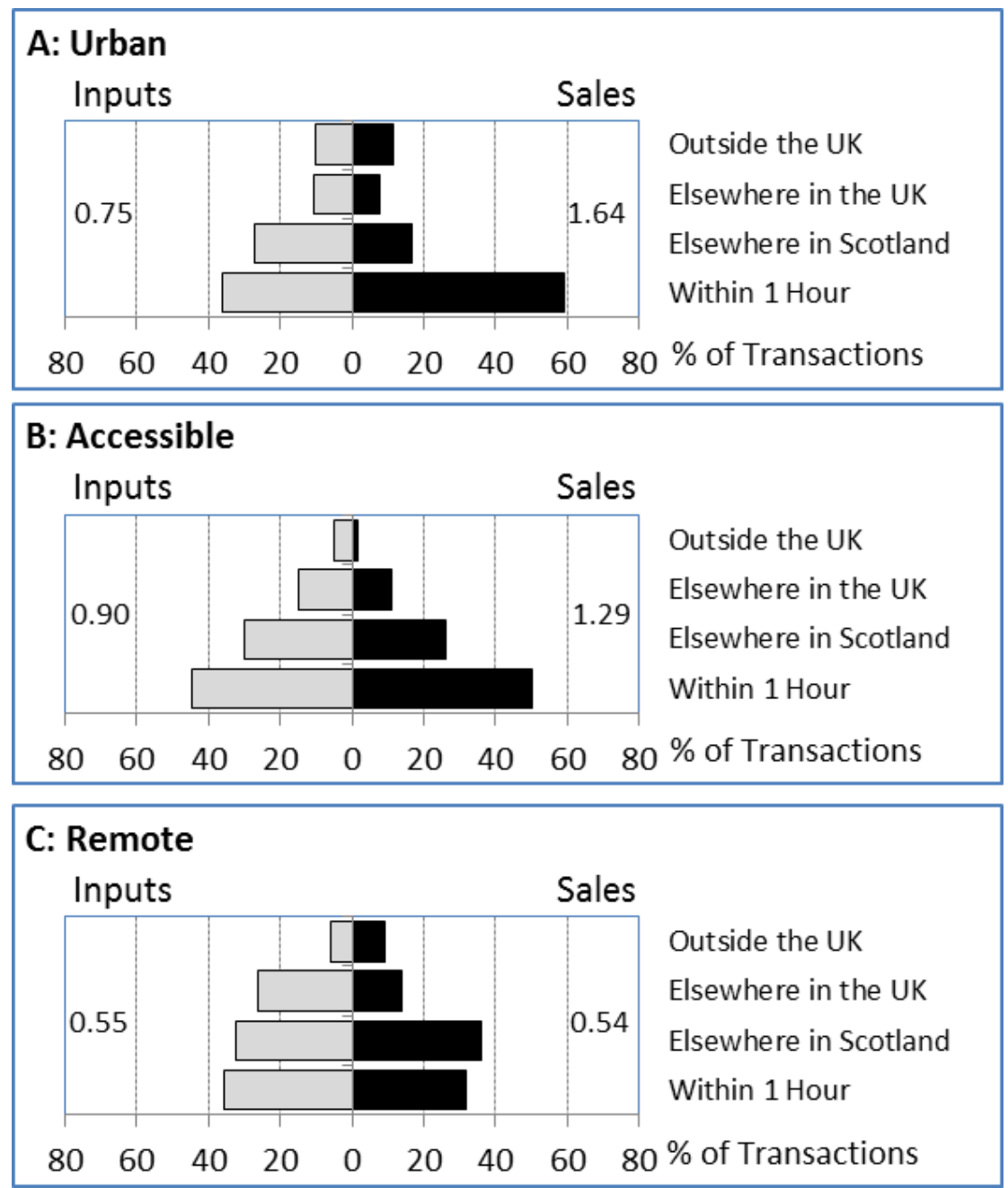

Fig 4. Transaction Footprint, respondents split by remoteness.

Almost one third (32\%) of all inputs for remote SMEs come from outside Scotland, compared with only a fifth in the accessible areas. Remote SMEs have a substantially lower input localisation ratio $(0.55)$ than the accessible SMEs $(0.90)$. The urban SMEs obtain just over a fifth $(21 \%)$ of inputs from outside Scotland, and have an input localisation ratio of 0.75 .

In terms of customers, $23 \%$ of remote SME transactions go to customers outside Scotland, compared with about $13 \%$ for SMEs in accessible areas, and $19 \%$ for the urban-based SMEs. The advantages of having a large body of nearby customers, for both accessible and urban SMEs is very clearly shown by the fact that they make (on average) $50 \%$ and $59 \%$ of their sales transactions, respectively, to customers within one hour's travel time of the production site, giving them sales localisation ratios of 1.29 and 1.64. The equivalent ratio for the remote firms is just 0.54 .

These results seem to confirm the findings of a survey in Northern Sweden, carried out with SMEs from a broad range of sectors, which suggested that small businesses in remote regions tend to have wider horizons in terms of their transaction networks because their sparsely populated environments cannot offer "critical mass" in terms of access to suppliers or customers. In Sweden this seemed to be associated with a focus on quality and niche markets (Copus et al. 2011, Dubois et al. 2012).

\section{Transaction patterns vary according to product}

It is of course reasonable to expect different kinds of product to be associated with different kinds of transaction pattern, depending upon perishability, bulkiness and value. On the whole perishable or bulky products have traditionally been associated with localised transaction patterns. However, some very perishable products, such as seafoods, can command sufficiently 
high prices to make international transaction footprints feasible. Of course modern logistics and preservatives can allow perishable products to be distributed over very long distances (as in the case of bakery products or frozen produce) - however such methods usually require economies of scale, and are thus less often associated with SMEs. Most of the product groups in Table 5 contain significant variations in scale of transaction footprints, indeed many food and drink producers have a rather mixed pattern of interaction, their product range including localised products as well as those involving longer distance transactions.

Tab 5. Localisation and transactions outside Scotland, by product Group.

\begin{tabular}{|l|r|r|r|r|r|}
\hline \multicolumn{1}{|c|}{ Main Product } & Respondents & $\begin{array}{r}\text { Input } \\
\text { Localisation } \\
\text { Ratio }\end{array}$ & $\begin{array}{r}\text { \% inputs } \\
\text { from } \\
\text { outside } \\
\text { Scotland }\end{array}$ & $\begin{array}{r}\text { Output } \\
\text { Localisation } \\
\text { Ratio }\end{array}$ & $\begin{array}{r}\text { \% sales } \\
\text { outside } \\
\text { Scotland }\end{array}$ \\
\hline Bakery products & 25 & 0.54 & 16.0 & 3.98 & 3.5 \\
\hline Dairy/cheese & 12 & 1.56 & 14.3 & 1.13 & 2.8 \\
\hline Drinks: alcoholic & 18 & 0.25 & 45.3 & 0.30 & 40.3 \\
\hline $\begin{array}{l}\text { Drinks: non- } \\
\text { alcoholic }\end{array}$ & 9 & 0.26 & 35.6 & 1.59 & 11.1 \\
\hline Fish/seafood & 13 & 0.98 & 11.7 & 0.19 & 44.3 \\
\hline Fruit/vegetables & 4 & 2.08 & 17.5 & 1.50 & 5.0 \\
\hline Grains/cereals & 4 & 0.48 & 12.5 & 1.05 & 25.5 \\
\hline Meat products & 15 & 0.74 & 12.7 & 2.73 & 2.9 \\
\hline $\begin{array}{l}\text { Processed/ready } \\
\text { meals }\end{array}$ & 10 & 0.75 & 25.5 & 1.33 & 11.2 \\
\hline Other & 13 & 0.67 & 33.5 & 1.38 & 17.0 \\
\hline
\end{tabular}

\section{Short supply chains associated with wider distribution footprints?}

Grouping firms by proportion of inputs purchased direct from producers or catchers (Figure 5) reveals some interesting differences in transaction footprint. The 29 respondent firms which used no inputs purchased direct from producers/catchers have a fairly broad based input catchment. About a quarter, (26\%) of their inputs are brought in from outside Scotland, whilst roughly the same proportion, (25\%), are purchased from suppliers within an hour's travel time. The output part of the footprint was much more localised $(0.81)$, with only $19 \%$ of transactions outside Scotland. Presumably this reflects the relatively low value market segment into which these products are directed.

The 11 respondents who used less than $50 \%$ of "fresh" inputs had an even less local input footprint, with a localisation ratio of 0.29 . The output side is by contrast highly localised (1.43), perhaps due to the combination of greater perishability but relatively low value of the products.

27 firms reported purchasing between $50 \%$ and $99 \%$ of their inputs from producers/catchers. These had a more localised input catchment (0.70); 79\% of transactions being within Scotland. The output part of the footprint was also extremely localised (1.54), 58\% of sales transactions taking place within the 1 hour travel zone. Again this is presumably due transport costs due to perishability or bulk.

The final group of 30 firms dealt only with inputs purchased direct from producers and catchers. Their footprint suggests that they process high value fresh foods for a (more distant) premium market. On the input side transaction patterns are highly localised (1.22), 53\% coming from the inner-most zone. On the output side the footprint is much less local (0.82). About one-third, (30\%) of all sales transactions cross the Scottish border. 

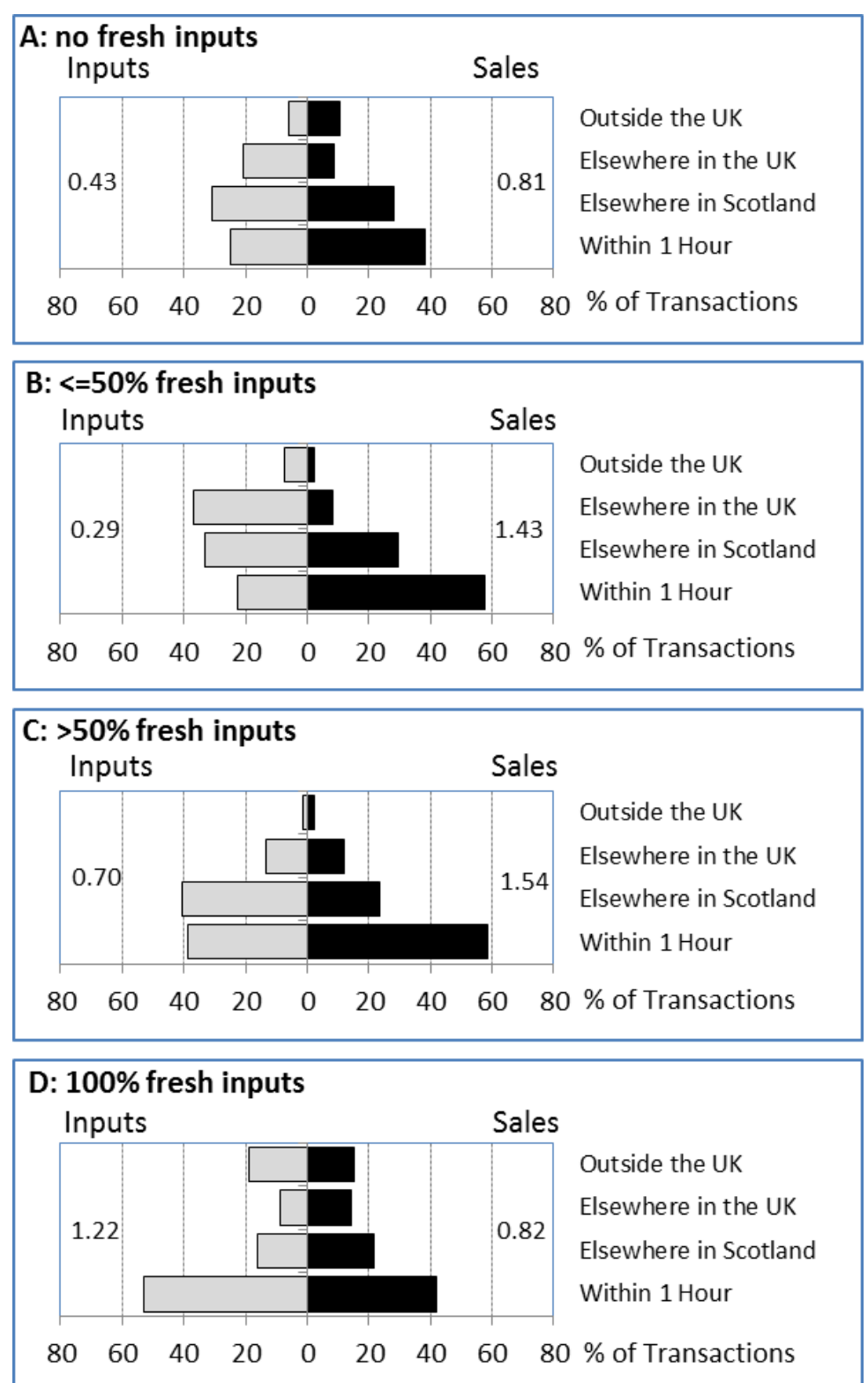

Fig 5. Transaction Footprints by Percentage of Inputs purchased direct from Producer or Catcher.

\section{Niche or Mass Market Orientation affects the size of Transaction Footprints}

Those SMEs which claim to be mass market orientated obtain $25 \%$ of their inputs from suppliers within an hour of their production site (Figure 6) resulting in an input localisation ratio of 0.49 . However a further $39 \%$ of input transactions involve suppliers within Scotland, and only $7 \%$ from outside the UK. Those which are niche market orientated obtain a larger proportion (on average $39 \%$ ) from within an hour's travel-time from their production facility, giving them an input localisation ratio of 0.65 . However compared with the mass market businesses they also bring in more inputs from elsewhere in the UK and outside the UK.

In terms of customers the mass market producers sell $72 \%$ of their produce in Scotland, and $10 \%$ further afield. Their output localisation ratio is 1.43. A larger proportion (21\%) of the niche producers' products are sold out of Scotland (output localisation ratio 1.13), presumably because they can command premium prices which can cover higher transport costs. Strangely, those SMEs which claim to serve both niche and mass markets have a relatively small input footprint (input localisation ratio 0.82 ), but sell $26 \%$ of their products to customers outside Scotland, and have a relatively small output localisation ratio of 0.62 . 

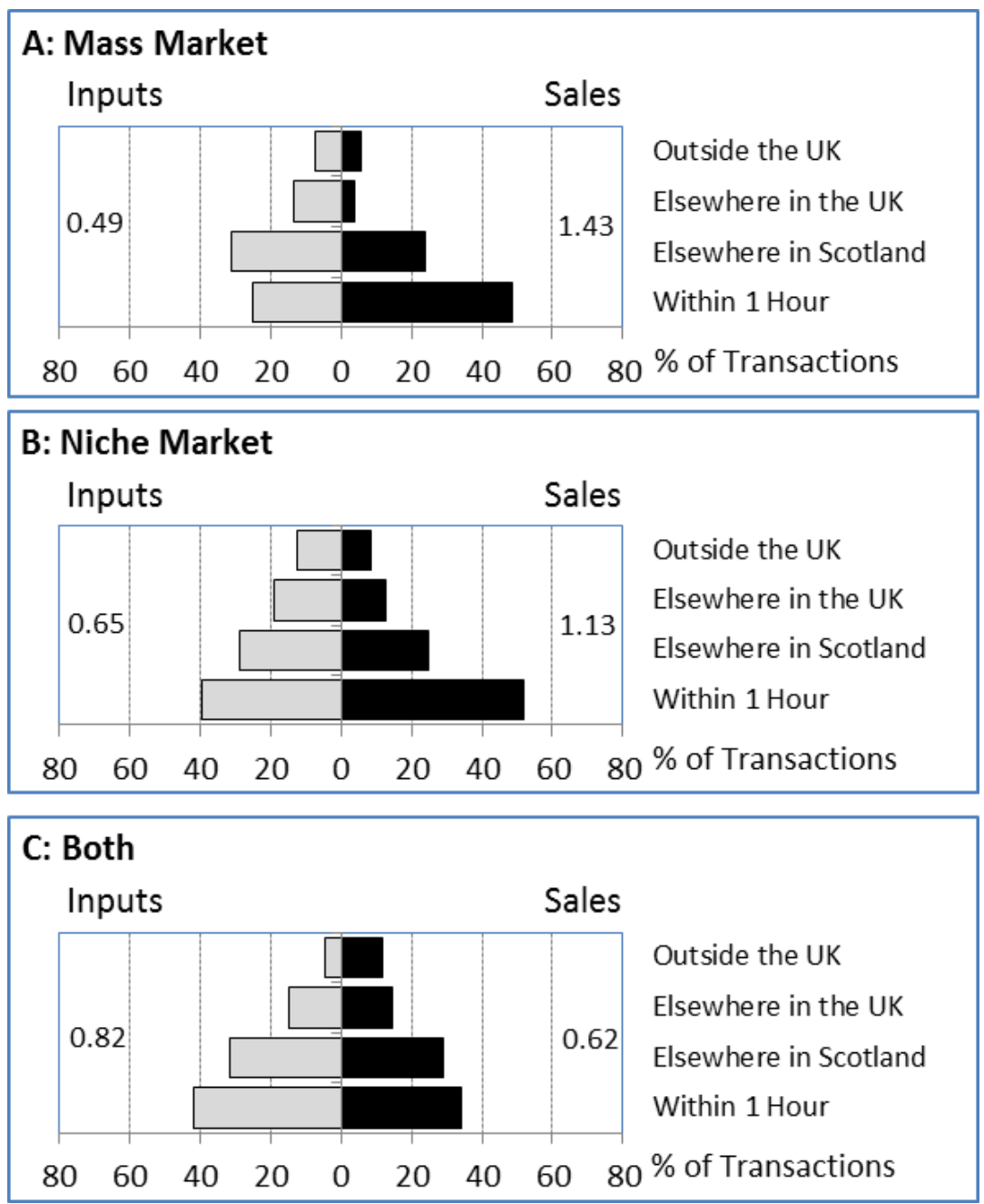

Fig 6. Niche and Mass Market Footprints.

\section{Internet trading widens the horizons}

Across the entire sample of respondents about $8 \%$ of input and $10 \%$ of output transactions were carried out online.
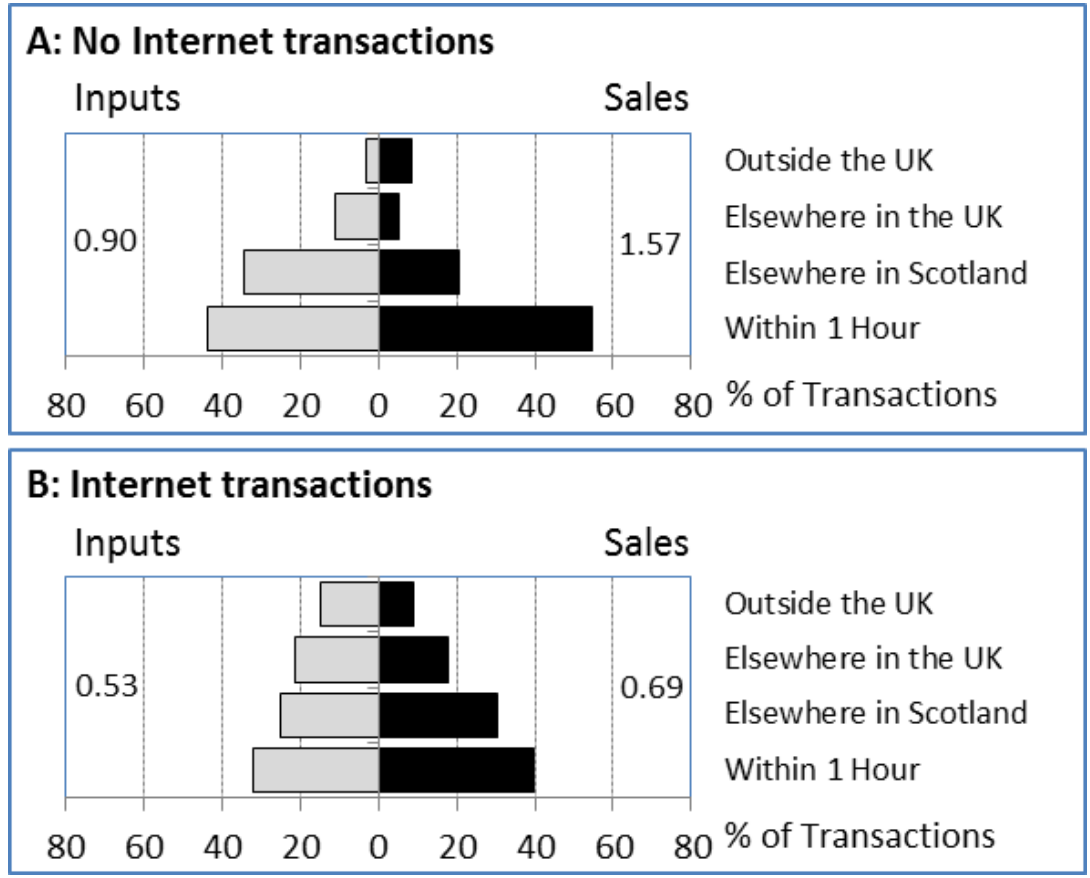

Fig 7. Effect of Internet use for purchasing and sales on Transaction Footprints. 
It is perhaps reassuring rather than surprising that firms which carried out transactions over the internet tended to have less localised transaction footprints than those which did not use online purchasing or sales methods. Thus firms which did not transact online carried out $78 \%$ of input purchases and $76 \%$ of sales within Scotland. Those which used online methods obtained $57 \%$ of inputs and made about $70 \%$ of sales within Scotland.

\section{Are wider footprints associated with better performance or growth?}

The responses to the three questions relating to economic performance and prospects are difficult to interpret in terms of their relationship with transaction footprints. In summary (Table 6), a majority, (62\%) of firms claimed that they were still experiencing ongoing recession effects, but the respondents were roughly equally split (between Average/Poor and Good) in terms of their assessment of their current performance. Looking ahead a clear majority (68\%) were optimistic, judging their prospects to be good rather than average or poor.

Tab 6. Summary of responses to questions about Recession impacts, Current and Future Performance.

\begin{tabular}{|l|r|r|r|r|r|}
\hline & Responses & $\begin{array}{r}\text { Localisation } \\
\text { Ratio }\end{array}$ & $\begin{array}{r}\text { Inputs } \\
\text { from } \\
\text { outside } \\
\text { Scotland }\end{array}$ & $\begin{array}{r}\text { Output } \\
\text { Localisation } \\
\text { Ratio }\end{array}$ & $\begin{array}{r}\text { \% sales } \\
\text { outside } \\
\text { Scotland }\end{array}$ \\
\hline $\begin{array}{l}\text { Impact of recession: } \\
\text { Slightly / } \\
\text { Substantially }\end{array}$ & 59 & 0.66 & 20 & 0.92 & 25 \\
\hline $\begin{array}{l}\text { Impact of recession: } \\
\text { Not at all }\end{array}$ & 36 & 0.70 & 35 & 1.28 & 13 \\
\hline $\begin{array}{l}\text { Current financial } \\
\text { health: Average / } \\
\text { Poor }\end{array}$ & 50 & & & & \\
\hline $\begin{array}{l}\text { Current financial } \\
\text { health: Good }\end{array}$ & 46 & 0.79 & 25 & 1.03 & 21 \\
\hline $\begin{array}{l}\text { Financial prospects: } \\
\text { Average / Poor }\end{array}$ & 31 & 0.57 & 27 & 1.07 & 19 \\
\hline $\begin{array}{l}\text { Financial prospects: } \\
\text { Good }\end{array}$ & 65 & 1.00 & 21 & 1.26 & 18 \\
\hline
\end{tabular}

The relationship between recession impacts, performance and perceived prospects on the one hand, and transaction footprints on the other, is far from clear. Respondents which claimed no ongoing recession impacts had slightly higher localisation ratios, on both the input and sales side. They derived a smaller proportion of inputs from outside Scotland but at the same time made a higher proportion of sales outside Scotland.

Those firms which considered their current performance to be good had (on average) lower input localisation ratios, and obtained a slightly greater share of inputs from outside Scotland. On the sales side their localisation ratio was marginally higher, and they made a smaller proportion of sales outside Scotland. Respondents who believed their business prospects were good had more localised input footprints, but were slightly less localised (than the pessimistic respondents) in terms of their sales transactions. 

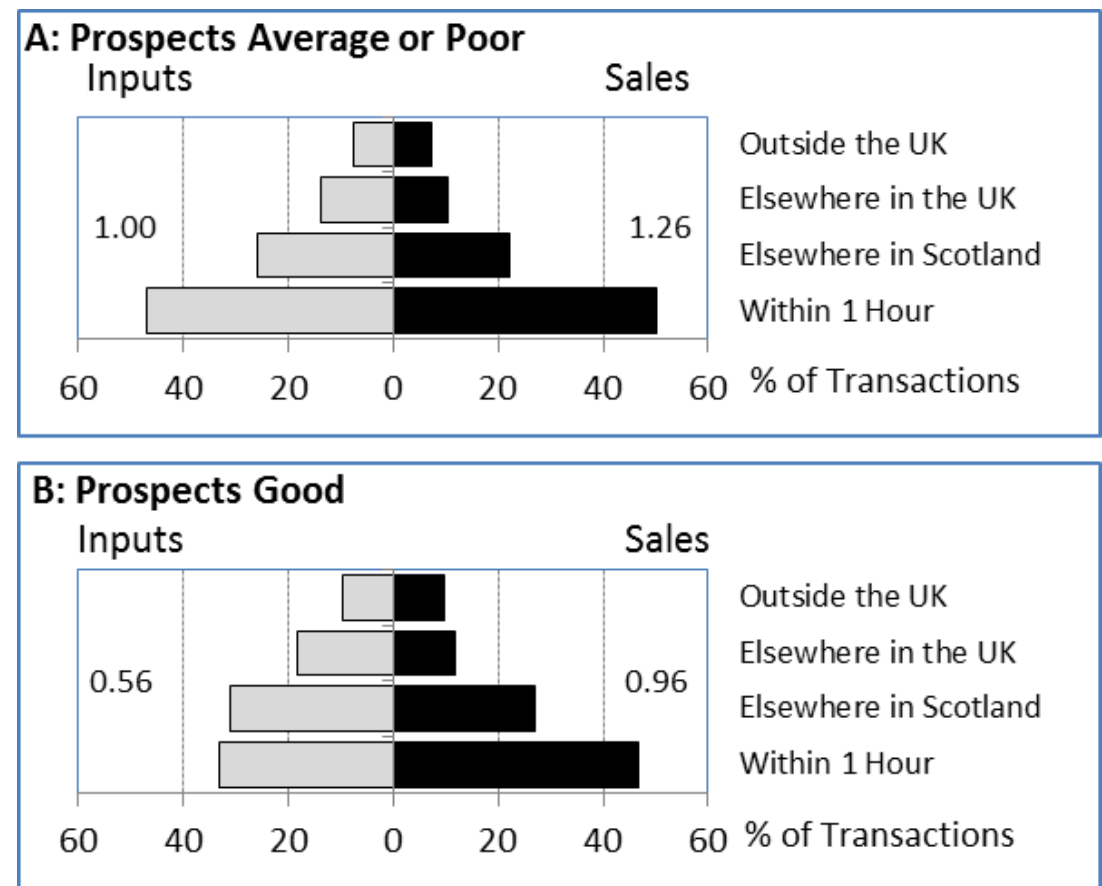

Fig 8. Transaction Footprints for Respondents who perceived their Future Prospects as Average/Poor and Good.

\section{Conclusions and Further Research}

The above analysis has demonstrated a practicable and replicable survey-based approach to quantifying the transaction-based spatial interaction patterns of the food and drink manufacturing sector in Scotland. The use of the Companies House register as a basis for sampling provides the potential for geo-referencing the respondent database, allowing bespoke spatial analysis of a range of research hypotheses. It has further been demonstrated that a carefully designed postal questionnaire is an economic means to acquire data, and that acceptable response rates are feasible without recourse to the expensive face-to-face interviews used by several previous studies. The graphical analysis and localisation ratios succinctly summarise the spatial data, but also offer a basis for quasi-objective benchmarking. This approach has already yielded useful data regarding interaction patterns among food and drink companies. It has shown, for example, that transaction footprints are affected by product type, marketing strategies, accessibility/remoteness, and the use of online trading. There is some evidence to suggest that a more outward-looking trading pattern is associated with greater optimism about the future.

Nevertheless there is also considerable scope for further development of the procedures reported above. One of the most important improvements would be to increase the sample size (for example by broadening the coverage across the SIC) so that robust statistical analysis and significance testing can be carried out. A high priority in terms of developing the questionnaire would be to find a concise way to incorporate estimates of the spatial distribution of the volume and/or value of transactions. Although the desirability of this was appreciated when designing the questionnaire (Appendix 1), previous experience suggested that additional complexity would seriously impact upon response rates. However further consideration should be given to this. Another improvement could be the incorporation of non-transactional interactions into the questionnaire, though it seems likely that this would need to be tackled in a rather different way to that used to capture transaction patterns. An additional face-to-face survey may be necessary.

The wider potential of the procedure will only be realised if it is extended to a range of different rural activities, so that comparative analysis can begin to piece together a picture of the way in which they coexist and interact in the "unfolding web" (van der Ploeg and Marsden 2008) of the rural economy. If, as the increasing interest in relational patterns and networking seems to suggest (Murdoch 2000, 2006, Shucksmith 2013, Bock 2016), the rural economy is on the cusp of an era in which its interactional fabric is being restructured, explicitly spatial analysis like this 
can reveal micro processes through which the bigger picture is evolving. There is, however, a sense in which transaction footprint analysis is like studying the back of a tapestry. It shows the vital connections between components of the rural economy, but the full picture can only be understood once these are placed within the context of a range of other kinds of interactions which form the evolving network infrastructure. Prominent among these are non-transaction linkages and institutional interactions within the realm of governance. A holistic view of these different layers of networking should be explored as a potential basis for a more appropriate paradigm for rural policy in twenty-first century Europe.

\section{Acknowledgement}

This research is funded by Scottish Government's Rural and Environmental Science and Analytical Services Division (RESAS) under Theme 8 'Vibrant Rural Communities' of the Food, Land and People Programme (2011 - 2016). The views expressed are those of the authors and do not necessarily reflect those of the Scottish Government.

\section{References}

[1] Barca, F. (2009). An Agenda for a reformed Cohesion Policy, a place-based approach to meeting European Union Challenges and expectations [Independent Report at the Request of Danuta Hübner, Commissioner for Regional Policy]. Available at:http://ec.europa.eu/regional_policy/archive/policy/future/barca_en.htm [Accessed on 28th March 2016].

[2] Bathelt, H., Malmberg, A. \& Maskell, P. (2004). Clusters and knowledge: local buzz, global pipelines and the process of knowledge creation. Progress in Human Geography, 28(1), 3156. Doi: 10.1191/0309132504ph469oa.

[3] Bathelt, H. \& Glückler, J. (2011). The relational economy: Geographies of knowing and learning. Oxford: Oxford University Press.

[4] Bock, B. (2016). Rural Marginalisation and the Role of Social Innovation; A Turn Towards Nexogenous Development and Rural Reconnection. Sociologia Ruralis (in press). DOI: $10.1111 /$ soru.12119.

[5] Bosworth, G. (2008). Entrepreneurial in-migrants and economic development in rural England. International Journal of Entrepreneurship and Small Business 6(3), 355-369. Doi: 10.1504/IJESB.2008.019132.

[6] Bosworth, G., (2012). Commercial counterurbanisation: an emerging force in rural economic development. Environment and Planning A, 42(4), 966-981. Doi: 10.1068/a42206.

[7] Boschma, R. (2005). Proximity and Innovation: A Critical Assessment, Regional Studies, 39(1), 61-74. Doi: 10.1080/0034340052000320887.

[8] Cairncross, F. (1997). The Death of Distance - How the Communications Revolution Will Change Our Lives. London: Orion.

[9] Copus, A., Skuras, D., MacLeod, M. \& Mitchell, M. (2003). The geography of transaction linkages in twelve European case study regions. [Paper to be presented at the 2003 Congress of the European Regional Science Association, Jyväskylä, Finland, 27th-30th August 2003]. Available at http://hdl.handle.net/10419/11611 .[accessed 28 ${ }^{\text {th }}$ March 2016].

[10] Copus, A., Dubois, A. \& Hedström, M. (2011). Expanding horizons: local embeddedness and local engagement among small firms in the European countryside. European Countryside, 3(3), 164-182. Doi: 10.2478/v10091-012-0002-y.

[11] Crowley, C., Walsh, J. \& Meredith, D. (2008). Irish farming at the Millennium - A Census Atlas. Maynooth: National Institute for Regional and Spatial Analysis.

[12] Courtney, P., Mayfield, L., Tranter, R., Jones, P. \& Errington, A. (2007). Small towns as 'subpoles' in English rural development: Investigating rural-urban linkages using sub-regional 
social accounting matrices, Geoforum, 38(6). 1219-1232. Doi: 10.1016/j.geoforum.2007.03.006.

[13] Courtney, P., Lepicier, D. \& Schmitt, B. (2008). Spatial patterns of production linkages in the context of Europe's small towns: How are rural firms linked to the local economy? Regional Studies, 42(3), 355-374. Doi: 10.1080/00343400701291542.

[14] Dubois, A., Copus, A. \& Hedström, M. (2012). Local embeddedness and global links in rural areas: Euclidean and relational space in business networks. Chapter 7 in Hedberg, C. \& Carmo, R., eds., 'Translocal Ruralism': Mobility and Connectivity in European Rural Space. Dordrecht: Springer.

[15] ESRI (2013) ArcGIS 10.2.1 for Desktop. Redlands, CA: Environmental Systems Research Institute.

[16] Fonte, M. (2008). Knowledge, food and place. A way of producing, a way of knowing. Sociologia Ruralis, 48(3), 200-222. Doi: 10.1111/j.1467-9523.2008.00462.x.

[17] Ilbery, B. \& Maye, D. (2005a). Alternative (shorter) food supply chains and specialist livestock products in the Scottish English borders. Environment and Planning A, 37(5), 823-844. Doi: $10.1068 / a 3717$.

[18] Ilbery, B. \& Maye, D. (2005b). Food supply chains and sustainability: evidence from specialist food producers in the Scottish/English borders. Land Use Policy 22(4), 331-344. Doi: 10.1016/j.landusepol.2004.06.002.

[19] Ilbery, B. \& Maye, D. (2006). Retailing local food in the Scottish-English borders: A supply chain perspective. Geoforum 37(3), 352-367. Doi: 10.1016/j.geoforum.2005.09.003.

[20] Kalantaridis, C. \& Bika, Z. (2006). Local embeddedness and rural entrepreneurship: casestudy evidence from Cumbria, England, Environment and Planning A 38(8), 1561-1579. Doi: $10.1068 /$ a3834.

[21] Korsgaard, S., Ferguson, R. \& Gaddefors, J. (2015). The best of both worlds: how rural entrepreneurs use placial embeddedness and strategic networks to create opportunities. Entrepreneurship \& Regional Development, 27(9-10), 574-598. Doi: $10.1080 / 08985626.2015 .1085100$.

[22] Marsden, T. (2009). Mobilities, Vulnerabilitues and Sustainabilities: Exploring Pathways from Denial to Sustainable Rural Development. Sociologia Ruralis 49(2), 113-131. Doi: 10.1111/j.1467-9523.2009.00479.x.

[23] Marsden, T. (2010). Mobilizing the regional eco-economy: evolving webs of agri-food and rural development in the UK. Cambridge Journal of Regions, Economy and Society, 3(2), 225-244. Doi: 10.1093/cjres/rsq010.

[24] Mitchell, M. \& Courtney, P. (2006). Economic Linkages Between Small Towns And Surrounding Rural Areas In Scotland. [Report for the Scottish Executive, Aberdeen]. Available at http://www.gov.scot/Publications/2005/03/20911/55370 [accessed 28th March 2016].

[25] Murdoch, J. (2000). Networks-A new paradigm of rural development. Journal of Rural Studies, 16(4), 407-419. Doi: 10.1016/S0743-0167(00)00022-X.

[26] Murdoch, J. (2006). Networking rurality: emergent complexity in the countryside, (pp. 171184). In Cloke, P., Marsden, T. \& Mooney, P., H., eds., Handbook of Rural Studies. London: Sage.

[27] Ploeg, J., van der \& Marsden, T. (2008). Unfolding webs: the dynamics of regional rural development. Assen: Royal van Gorcum.

[28] Piore, M. \& Sabel, C. (1984). The second industrial divide: Possibilities for prosperity. New York: Basic Books. 
[29] Pangbourne, K. \& Roberts, D. (2014). Small Towns and Agriculture: Understanding the Spatial Pattern of Farm Linkages, European Planning Studies, 23(3), 494-508. Doi: 10.1080/09654313.2013.872231.

[30] R Core Team (2015a) R: A language and environment for statistical computing. R Foundation for Statistical Computing, Vienna. https://www.R-project.org/ [accessed 30 ${ }^{\text {th }}$ March 2016].

[31] R Core Team (2015b) foreign: Read Data Stored by Minitab, S, SAS, SPSS, Stata, Systat, Weka, dBase, $\mathrm{R}$ package version 0.8-65. http://CRAN.R-project.org/package=foreign [accessed 30 ${ }^{\text {th }}$ March 2016].

[32] Ray, C. (2006). Neo-endogenous Rural Development in the EU (pp. 278-291). In Cloke, P., Marsden, T. \& Mooney, P., eds., Handbook of Rural Studies. London: Sage.

[33] Scottish Government (2013a). Food and drink success: New industry goal as turnover target smashed six years ahead of schedule, Press Release. http://news.scotland.gov.uk/News/Food-drink-success-3ee.aspx [accessed 26th March 2016].

[34] Scottish Government (2013b). Scottish Annual Business Statistics 2013. http://www.gov.scot/Resource/0048/00484162.pdf [accessed 26th March 2016.

[35] Scottish Government (2014). Scottish Government Urban Rural Classification 2013-2014, Edinburgh. Available at [http://www.gov.scot/Publications/2014/11/2763 ] Accessed 29 th March 2016].

[36] Scottish Government (2015). Businesses in Scotland, Edinburgh http://www.gov.scot/Topics/Statistics/Browse/Business/Corporate [Accessed 26th March 2016].

[37] Shucksmith, M. (2013). Future Directions in Rural Development - Full Report. Dunfermline: Carnegie UK Trust. Available at http://www.carnegieuktrust.org.uk/publications/2012/futuredirections-in-rural-development-\%28full-report [Accessed on $28^{\text {th }}$ March 2016].

[38] Sonnino, R. \& Marsden, T. (2006). Beyond the divide: rethinking relationships between alternative and conventional food networks in Europe. Journal of Economic Geography 6(2), 181-199. Doi: 10.1093/jeg/lbi006.

[39] Storper, M. (1995). The resurgence of regional economies, ten years later, the region as a nexus of untraded interdependencies. European Urban and Regional Studies 2(3), 191 221. Doi: $10.1177 / 096977649500200301$.

[40] Torre, A. \& Rallet, A. (2005). Proximity and localisation. Regional Studies, 39(1), 47-59. Doi: $10.1080 / 0034340052000320842$.

[41] Watts, D., Leat, P. \& Revoredo-Ghia, C. (2011). Local Food Activity in Scotland: Empirical Evidence and Research Agenda, Regional Studies 45(9), 1187-1205. Doi: $10.1080 / 00343400903380416$.

[42] Young, N. (2010a). Globalization from the edge: a framework for understanding how small and medium-sized firms in the periphery 'go global', Environment and Planning A, 42, 838855.

[43] Young, N. (2010b). Business networks, collaboration and embeddedness in local and extralocal spaces: the case of Port Hardy, Canada. Sociologia Ruralis 50(4), 392-408. Doi: 10.1111/j.1467-9523.2010.00521.x. 


\section{APPENDIX 1: The Questionnaire}

\section{$\approx$ inim hutron

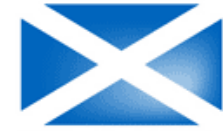 \\ The Scottish \\ Government \\ Riaghaltas na h-Alba Local or \\ Global? \\ A short survey on business interactions within the Scottish food and drink industry}

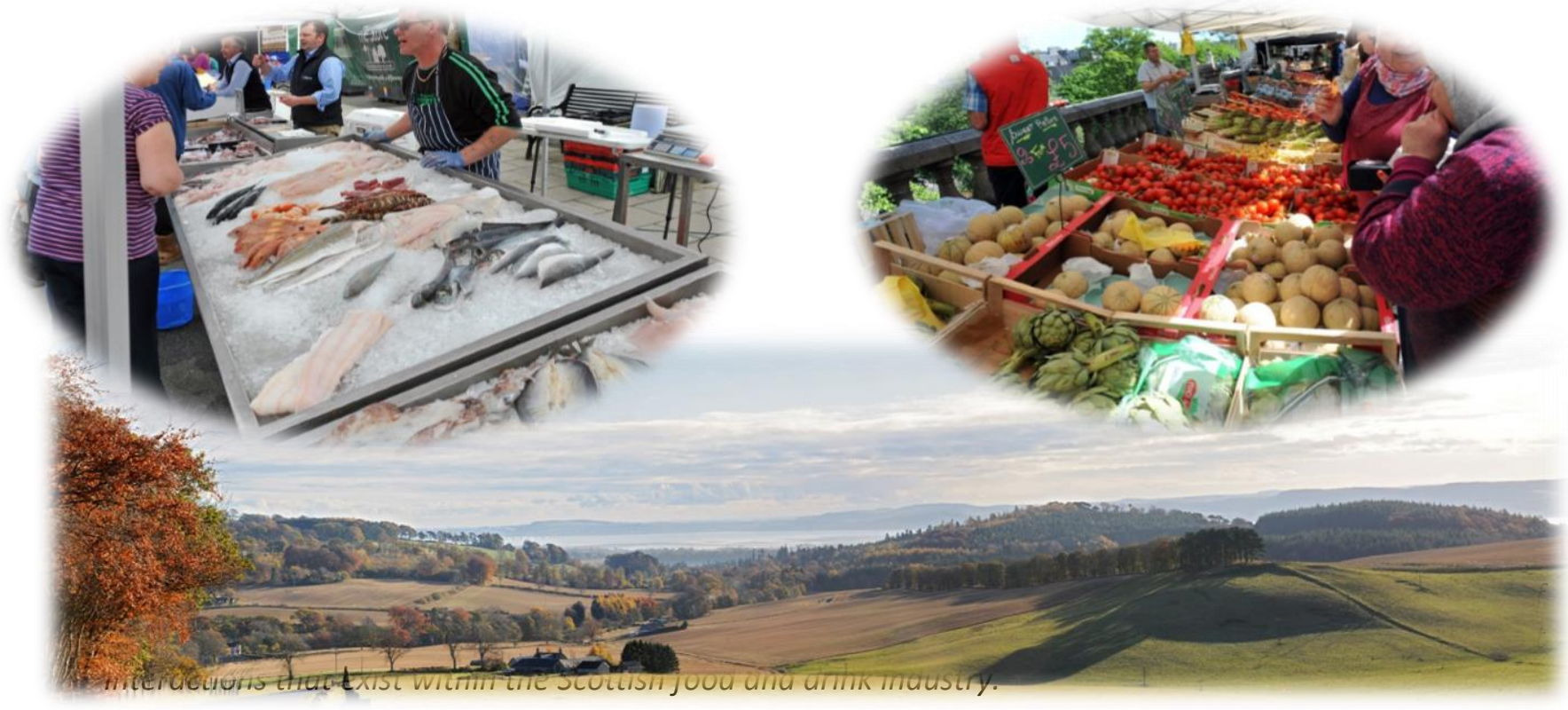

About your Business

Q1 What is the name of your business and the postcode of your main production site?

Name:

Postcode:

Q2a How many production sites do you have in total?

Q2b Where are these other production sites located? Please provide the postcodes, or nearest village or town if you are unsure of the postcodes:

Q3 Including yourself, how many staff does your business have?

Number of full-time staff: __ Number of part-time staff:

Q4 Do you supply products for the mass market or for a niche market? Please tick one:
Mass market
Niche market
Both

Q5 What are your main products? Please tick all that apply and provide an example if you tick 'Other':
Bakery products
Drinks: non-alcoholic
Fruit/vegetables
Other e.g.

$\begin{array}{ll}\bigcirc & \text { Dairy/cheese } \\ \text { Grains/cereals } \\ \text { Meat products }\end{array}$
Drinks: alcoholic
Fish/seafood
Processed/ready meals




\section{Your Business Inputs}

* Please estimate (to the nearest 10\%) percentages in terms of number of transactions (rather than in terms of quantities or values of goods). Please ensure your percentages add up to $100 \%$ per question.

Q6* In what form do you obtain your main inputs?

Directly from the producer/catcher

$\%$ Semi-processed

Q7a* Where do you mainly obtain your inputs from?

Within 1 hour travel

Elsewhere in the UK

$\%$

$\%$

Elsewhere in Scotland

Outside the UK

Q7b* How would you describe the location of the businesses from which you obtain your inputs?

Village and/or countryside

$\%$ Town and/or city

$\%$ Unknown

Q7c How have your suppliers and inputs changed over the last 5 years?

Not at all

Substantially

\section{Your Customers}

\footnotetext{
* Please estimate (to the nearest 10\%) percentages of customers in terms of their number of transactions (rather than in terms of quantities or values of goods). Please ensure your percentages add up to $100 \%$ per question.
}

Q8* How would you describe your customers?

$\begin{aligned} & \text { Consumers (i.e. } \\ & \text { the general } \\ & \text { public) }\end{aligned}$
Q9a* How far away from your main production site are your customers located?
Within 1 hour travel
staff
Elsewhere in the UK

Businesses with $250+$ staff

Q9b* What kinds of customers do you sell to?

Businesses in village or countryside locations

Consumers (i.e. the general public) in village or countryside locations

$\%$ Businesses in town or city locations

$\%$ Consumers (i.e. the general public) in town or city locations

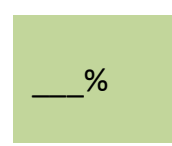

\section{Your Distribution Methods}

Q10* Do you carry out transactions over the internet? Please tick one option. If you tick 'Yes' please record percentages (of your total number of transactions).
No
$\%$ of purchases
$\%$ of sales
Yes

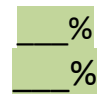

Q11 Which distribution method(s) do you mainly use to sell your products? Please tick the appropriate response for each method and give an example in the green shaded area if you use another method.
Distribution Method
Never
used
Occasionally
Frequently used
Solely

$\begin{array}{ll}\text { used } & \\ \bigcirc & \\ \bigcirc & \bigcirc \\ \bigcirc & \bigcirc \\ \bigcirc & \bigcirc\end{array}$

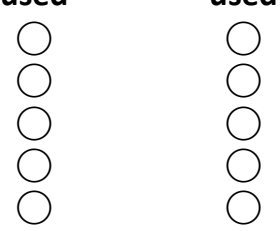
used

\section{Couriers or the Royal Mail}
Customers coming to your main production site Farmer's markets
Own delivery vans
Other e.g.

Q12 Is your business a member of any of the following groups? Please tick all that apply and give the names of the groups if possible:
Chamber of commerce
Co-operatives 
Q13a On a scale of 1 to $\mathbf{5}$, in which 1 represents 'mainly local sales' and $\mathbf{5}$ represents 'sales at all levels across the globe', where would you say your business was five years ago? Please circle the number you feel best represented your business then:

$$
\begin{array}{lcl}
\text { Selling } & \text { Selling } & \text { Selling } \\
\text { Locally } & \text { Scottish } & \text { Globally }
\end{array}
$$

Q13b Where would you say yo 1 , busine ${ }_{2}^{2}$ is now? ${ }^{3}$, lease circ. ${ }^{4}$ the num ${ }^{5}$ er you feel best represents your business now:

$\begin{array}{lcc}\text { Selling } & \text { Selling } & \text { Selling } \\ \text { Locally } & \text { Scottish } & \text { Globally }\end{array}$

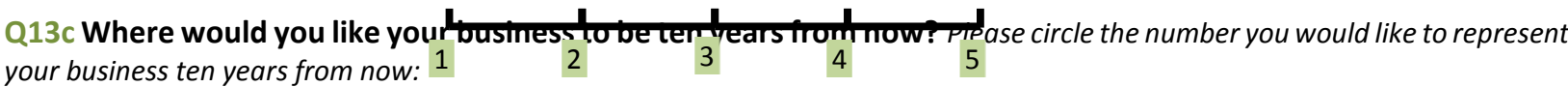

2

$\begin{array}{lcc}\text { Selling } & \text { Selling } & \text { Selling } \\ \text { Locally } & \text { Scottish } & \text { Globally }\end{array}$

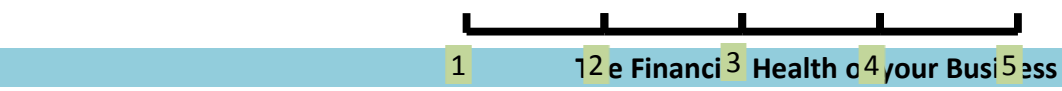

Q14 To what extent is your business still being negatively impacted by the recession? Please tick one:
Not at all
Slightly
Substantially

Q15 Which statement would best describe the current (financial) health of your business? Please tick one:
Poor
Average
Good

Q16 What are your prospects for the (financial) health of your business in the next five years? Please tick one:
Poor
Average
$\bigcirc$ Good

Q17 What sources do you currently receive funding from? e.g. Scottish Enterprise etc.

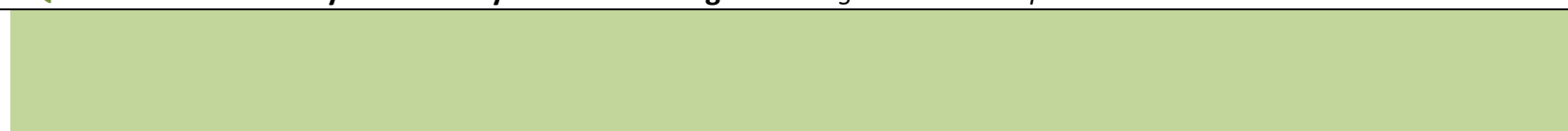

Many thanks for filling in the survey. Please return the completed survey in the prepaid envelope at your earliest convenience. If you would like to receive a copy of the findings please include your email address below and do not hesitate to contact us if you have any questions.

Rachel Creaney (rachel.creaney@hutton.ac.uk / 01224 395287); Andrew Copus and Jonathan Hopkins. Social Economic and Geographical Sciences, James Hutton Institute, Craigiebuckler, Aberdeen, AB15 8QH

Email Address: 